\title{
Post-earthquake ignition vulnerability assessment of Küçükçekmece District
}

\author{
S. S. Yildiz ${ }^{1}$ and H. Karaman ${ }^{2}$ \\ ${ }^{1}$ Department of Geodesy and Photogrammetry Engineering, Faculty of Engineering, Osmaniye Korkut Ata University, \\ 80000 Osmaniye, Turkey \\ ${ }^{2}$ Department of Geomatics Engineering, Faculty of Civil Engineering, Istanbul Technical University, \\ 34469 Istanbul, Turkey
}

Correspondence to: H. Karaman (karamanhi@itu.edu.tr)

Received: 6 February 2013 - Published in Nat. Hazards Earth Syst. Sci. Discuss.: 17 May 2013

Revised: 9 November 2013 - Accepted: 21 November 2013 - Published: 19 December 2013

\begin{abstract}
In this study, a geographic information system (GIS)-based model was developed to calculate the postearthquake ignition probability of a building, considering damage to the building's interior gas and electrical distribution system and the overturning of appliances. In order to make our model more reliable and realistic, a weighting factor was used to define the possible existence of each appliance or other contents in the given occupancy. A questionnaire was prepared to weigh the relevance of the different components of post-earthquake ignitions using the analytical hierarchy process (AHP). The questionnaire was evaluated by researchers who were experienced in earthquake engineering and post-earthquake fires. The developed model was implemented to HAZTURK's (Hazards Turkey) earthquake loss assessment software, as developed by the MidAmerica Earthquake Center with the help of Istanbul Technical University. The developed post-earthquake ignition tool was applied to Küçükçekmece, Istanbul, in Turkey. The results were evaluated according to structure types, occupancy types, the number of storeys, building codes and specified districts. The evaluated results support the theory that postearthquake ignition probability is inversely proportional to the number of storeys and the construction year, depending upon the building code.
\end{abstract}

\section{Introduction}

Fires following earthquakes (FFE) can induce destructive damage. Damage caused by FFE can sometimes exceed the loss from direct damage caused by the earthquake. Many factors affect the intensity of FFE, such as the ignition sources, the types and density of fuel, weather conditions, the operation of water systems and the ability of firefighters to suppress the fires (HAZUS, 1999).

Earthquakes not only cause damage by shaking, but secondary disasters like fires, following an earthquake, tsunami, liquefaction, land slide, etc., also cause large-scale losses. In some cases, fires following earthquakes and tsunamis result in more losses than from the shaking (e.g., as shown in the 1906 San Francisco earthquake and the 1923 Kanto earthquake). Fires following earthquakes is the only issue investigated in this study.

Post-earthquake urban fires are generally caused by strong ground shaking. Strong shaking damages the structures and lifelines of cities, such as water, electrical and gas systems. Heavy damage to the electrical and gas systems can result in leakage, which can cause many simultaneous fire ignitions. Moreover, many ignitions also occur due to the overturning of electrical appliances, heating equipment or flammable materials within structures. In addition to inner structure ignitions, damaged infrastructure elements, such as gas mains and pipelines, as well as damaged electrical transmission lines, can also cause ignitions. Some of these ignitions are put out by occupants and therefore do not induce much more damage. Some of them spread due to the amount of 
fuel available (combustible materials), the actual construction material, water capacity, firefighting capabilities, an inadequate number of firebreaks, the direction and speed of wind, any of which can turn these ignitions into large urban conflagrations. All of these effects can cause many destroyed buildings, numerous deaths and injuries, along with enormous economic losses.

Furthermore, firefighting activities are also a significant factor that can directly influence the spread of fire. The more a fire department's response is delayed, the further a fire can spread. Fire departments often have difficulties in reaching a fire when acting in response to a call after an earthquake, due to narrowed streets, closed roads, collapsed buildings, damage to their fire stations and injuries to firefighters, etc.

During firefighting activities, firefighters need highly pressured water and chemical materials to extinguish a fire. Strong earthquakes damage water mains and pipelines. Water systems frequently sustain many breaks and this can result in a reduction in water pressure that can cause difficulties for the firefighters.

Strong earthquakes also damage the communication systems in the affected area. Communication systems play an important role in fire response. Dispatching firefighters to different fires from a central fire department prevents all of them from responding to the same fire and optimizes time efficiency.

The most common FFEs are caused by the restoration of an electricity supply in red-tagged buildings, which are unsafe and where nobody is allowed to enter. If there is a gas leak in the building, it will be ignited when the electrical power is restored.

As mentioned before, some FFEs can cause much more damage than the earthquakes themselves, as shown in the 1906 San Francisco and the 1923 Kanto earthquakes. Most of the fires following the 1906 San Francisco earthquake occurred because of several ruptures in gas mains and pipelines. Scawthorn et al. (2006) stated that post-earthquake ignitions led to large urban conflagrations because of highly flammable construction, inadequate fire protection and an inadequate water supply in the 1906 San Francisco earthquake. In the 1923 Kanto earthquake, 277 fires occurred because of small charcoal braziers that were widely used for cooking at lunchtime (Scawthorn et al., 2005).

Within the scope of this study, a probabilistic postearthquake ignition model was developed. This postearthquake ignition model has been developed to estimate the ignition probabilities of structures by considering real sources. This paper represents the application of this model in the Küçükçekmece District of Istanbul, Turkey.

\section{Background}

Research on urban fire spread started in the 1950s because of large urban conflagrations caused by fire bombing dur- ing World War II (Martin, 2004). Hamada expressed the importance of FFE after the 1948 Fukui earthquake and subsequent major conflagrations within the affected areas (US Army, 1949). The first model was developed by Hamada and consists of a set of equations that estimate urban fire spread using fuel load, wind speed and other factors as its input parameters (Hamada, 1951). After this model was developed, some Japanese scientists continued to study this topic in the 1970s (Horiuchi et al., 1974; Mizuno and Horiuchi, 1976; Mizuno, 1978; Lee et al., 2008).

In contrast, there were no studies about FFE in the United States until Steinbrugge (1968) mentioned the FFE problem in the San Francisco Bay Area and collected data about it (Steinbrugge, 1971). There were also no FFE models, only several researchers who collected data and started defining the FFE problem (Oppenheim, 1984). Scawthorn developed the first integrated FFE model that includes post-earthquake ignitions, their spread and fire department responses in the late 1970s and early 1980s. This model was first applied in Japan (Scawthorn et al., 1981) and later in California (Scawthorn, 1986). The model was used as a source for the insurance industry and other modeling approaches for a long time (Lee et al., 2008).

Many scientists used their research to estimate the number of post-earthquake ignitions and they developed different models. Most of these models depended on ground motion. There have been some studies about multi-parameter ignition models in the last couple of years. Kawasumi developed an equation by using logarithmic regression analysis (Kawasumi, 1961; Kobayashi, 1984; Aoki, 1990; Scawthorn et al., 2005; Zhao et al., 2006). He only used data from the 1923 Kanto earthquake and showed a positive correlation between the rate of ignitions and the rate of collapsed wooden buildings. Mizuno developed an equation to estimate post-earthquake ignitions (Mizuno, 1978; Kobayashi, 1984; Aoki, 1990; Zhao et al., 2006) by proving a logarithmic regression relationship between the rate of ignitions per household and the rate of totally collapsed households. An ignition model developed by Li et al. (2001) estimated possible ignitions in a specific zone with a certain level of probability. The model assumes that post-earthquake ignitions are in a Poisson distribution in time and place. The model calculates the incidence of ignitions according to the area of buildings with moderate or higher damage. A second-order equation was developed by modifying the ignition model developed by Scawthorn (1987) in order to use HAZUS (Hazard US) software. The new data points, representing the ignitions from the 1989 Loma Prieta earthquake, were taken into account; the ignition per single family equivalent dwelling (SFED) unit was changed to ignitions per $1 \mathrm{M} \mathrm{ft}^{2}$ of structure inventory and the MMI (Modified Mercalli Intensity) scale was converted to PGA (peak ground acceleration) scale (HAZUS, 1999). Scawthorn updated this equation by taking seven earthquakes (1971 San Fernando, 1983 Coalinga, 1984 Morgan Hill, 1986 N. Palm 
Springs, 1987 Whittier Narrows, 1989 Loma Prieta, 1994 Northridge) into consideration. A total of 238 data points were used in the regression equation. The number of ignitions per $92903.04 \mathrm{~m}^{2}$ of total floor area due to PGA is calculated by using Eq. (1) (Scawthorn, 2009).

Ignitions $=\left(0.581895 \mathrm{PGA}^{2}\right)-(0.029444 \mathrm{PGA})$

The URAMP software (Utilities Regional Assessment of Mitigation Priorities) estimates the post-earthquake ignition rate according to PGA or MMI for different types of building occupancy (residential, commercial and industrial) separately (Scawthorn et al., 2005). Ignition locations are determined randomly (Seligson et al., 2003). Cousins and Smith (2004) assumed that there is a linear relationship between the mean number of ignitions per millions of $\mathrm{m}^{2}$ of floor area and the shaking intensity (MMI). Ren and Xie (2004) modified the ignition equation of HAZUS by taking into account the post-earthquake fires that occurred in USA, Japan and China, between 1900 and 1996. They produced a new second-order relationship between the number of ignitions and PGA. Davidson (2009) developed two different models for two different data sets to estimate the number of ignitions per census tract, by using negative binomial regression models. Two data sets were developed to explore the possible effect of missing ignition data. Zolfaghari et al. (2009) estimated the ignition probability of a building with an analytical approach. Three ignition sources are considered, depending on ground motion and structural damage. Building utility damage, damaged braced nonstructural equipment and the overturning of braced equipment or contents are three main components of the model.

\section{Post-earthquake ignition and a probabilistic approach for post-earthquake ignition modeling}

Post-earthquake ignitions occur as a result of building damage caused by strong earthquakes. Internal gas pipes and electrical distribution systems suffer damage because of the strong shaking and this can result in a leakage of gas and sparking from the electrical distribution system. Appliances containing a fuel source, an electrical mechanism or bare flames within dwellings can also cause ignitions. Leakage from an internal gas system or the spilling of flammable materials from the overturning of appliances can be ignited by overturned electrical appliances, wiring failures in electrical distribution systems or bare flames. Shelves containing flammable materials, parked automobiles under buildings and structures containing chemical materials, like universities, are also ignition sources. Each of these sources has an influence on ignition occurrence. These sources should be modeled to estimate potential post-earthquake ignitions.

In this study, the probability of a post-earthquake ignition is estimated by considering the damage caused to a building's internal gas and electrical distribution systems, and the overturning of appliances. The developed model was implemented by HAZTURK's (MAEViz) earthquake loss assessment software, developed by the Mid-America Earthquake Center with the help of Istanbul Technical University.

The model consists of three main components - utility systems, hazardous appliances and contents, and less hazardous appliances and contents - covering the different sources of post-earthquake ignitions as shown in Fig. 1.

\subsection{Utility related post-earthquake ignition probability}

Ignitions that are caused by damage to utility systems include damage to interior gas and electrical distribution systems. Ignition probability caused by a damaged utility system is calculated in relation to building damage from a specific ground motion. The approach of Peyghaleh (2006) was adopted to calculate utility related ignition probability in the model. Building damage was created by using HAZTURK (MAEViz) software for a specific earthquake scenario. Utility related ignition probability is calculated with four different damage states - insignificant, moderate, heavy and complete - obtained from a building damage analysis executed with HAZTURK (MAEViz). A building damage file produced by different software can also be used when importing this file into HAZTURK (MAEViz). A mapping operation is necessary to link the attributes of an input file with the required attributes for the model. The occurrence of ignition was defined by using an event tree in Fig. 2.

Structural damage triggers pipeline and wiring damage. This pipeline and wiring damage can result in gas leakage and electrical sparks. Finally, an ignition is caused by combination of these gas leakage and electrical sparks. Ignition probability is calculated by using Eq. (2) (Zolfaghari et al., 2009), where OS is other sources, ECG is electrical short circuit given, SD is structural damage, WDG is wiring damage given structural damage, GLG is gas leakage given pipeline damage, PDG is pipeline damage given structural damage and FC is existence of other flammable contents.

$$
\begin{aligned}
P(\mathrm{Ig}) & =(P(\mathrm{OS})+P(\mathrm{ECG}) \times P(\mathrm{SD}) \times P(\mathrm{WDG}) \\
& \times P(\mathrm{GLG}) \times P(\mathrm{SD}) \times P(\mathrm{PDG})+P(\mathrm{FC})
\end{aligned}
$$

\subsection{Appliances and contents related post-earthquake ignition probability}

For hazardous and less hazardous appliances and contents, ignitions are caused by the overturning of appliances and the falling of flammable materials from shelves because of visible acceleration. Overturned appliances and fallen contents, including flammable material and appliances exposed to a live electrical current or bare flame, can produce ignitions. The probability of the overturning of appliances can be estimated by modeling the motion of the appliance due to acceleration.

The probability of ignition from appliances and other contents is obtained by using the methodology of Luis Esteva 


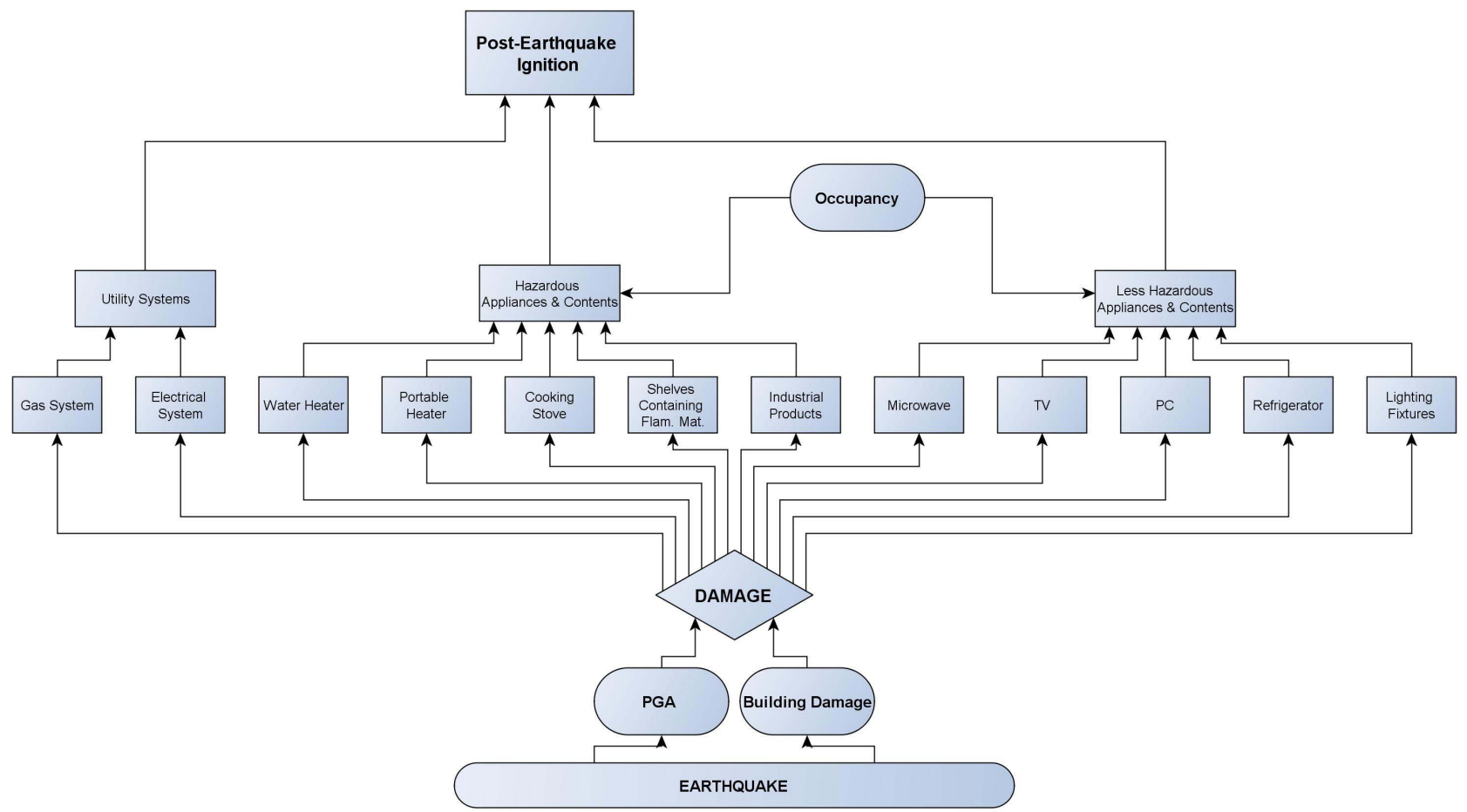

Fig. 1. Structure of post-earthquake ignition model.

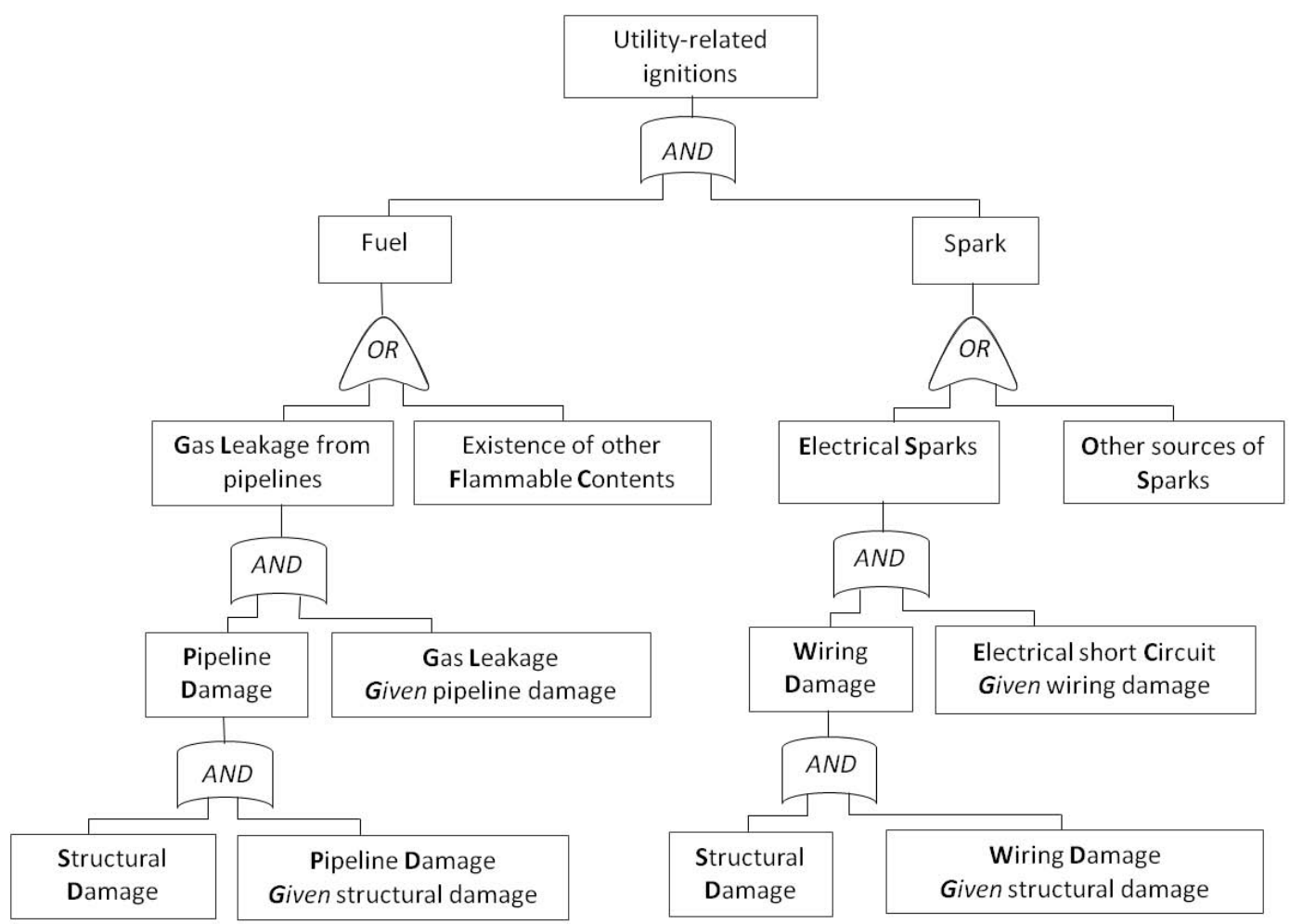

Fig. 2. Event tree of ignition probability caused by damaged utility systems (Peyghaleh, 2006). 


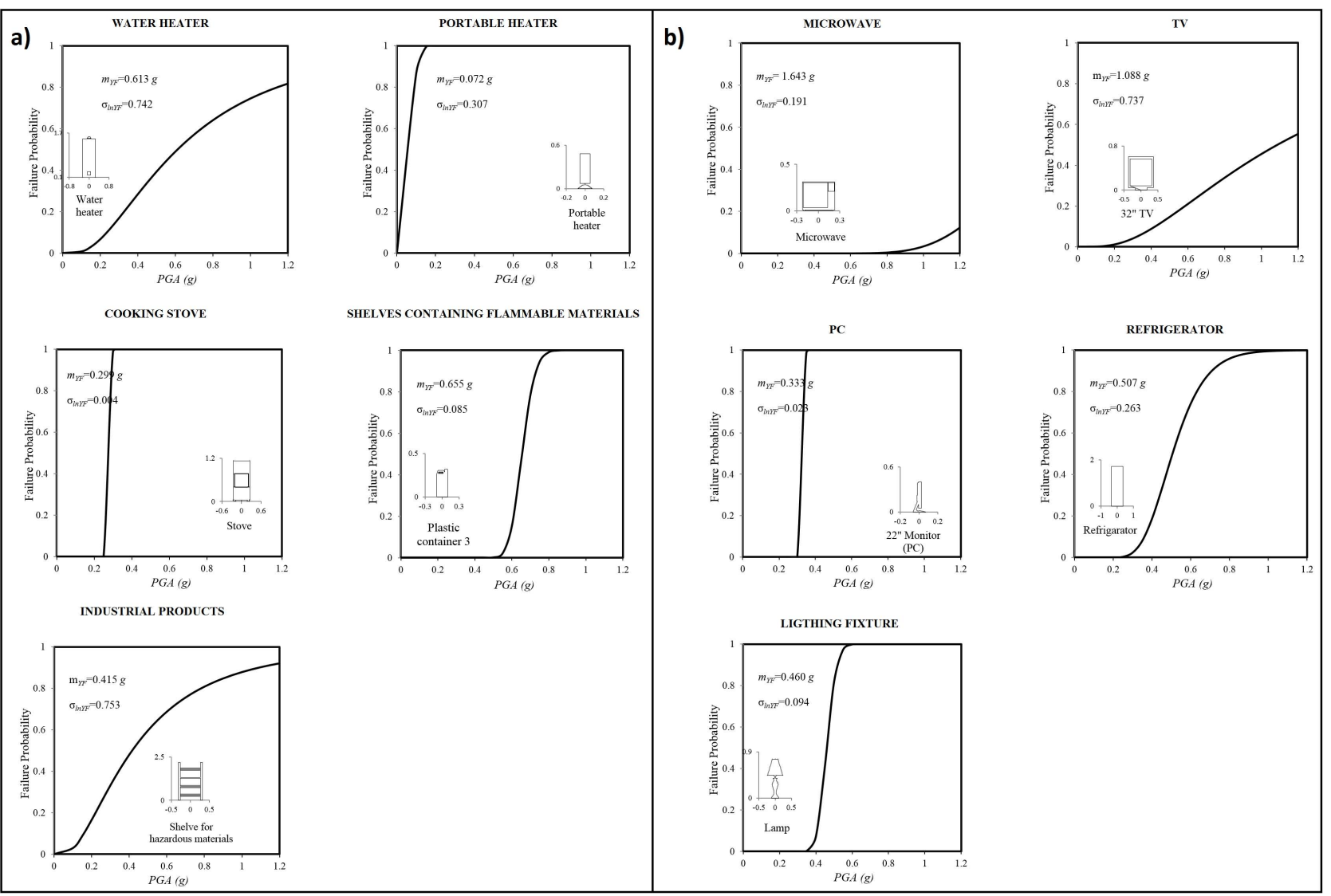

Fig. 3. Overturning probability for (a) hazardous appliances and (b) less hazardous appliances (Reinoso et al., 2010).

and his team from the Institute of Engineering at the National University of Mexico. According to Reinoso et al. (2010), the overturning of contents occurs when the horizontal acceleration exceeds the critical acceleration level defined for each object, based on its size and shape. Recorded ground motions from 21 different earthquakes were used to obtain the minimum PGA value needed to produce overturning for each object. After a value of the failure intensity is obtained for each ground motion time history, which is then adequately scaled, a sample will be available and a function $F_{\mathrm{YF}}(y)$ may be fitted to it, representing the probability distribution function of the minimum value of the intensity required to produce overturning.

The overturning probability of each object is calculated by using log-normal functions depending on exposed PGA value for a particular building (Eq. 3). Overturning probabilities were calculated according to the mean and standard deviation of experimental results with respect to the exposed PGA value.

$F_{\mathrm{YF}}(y)=\Phi\left[\frac{1}{\sigma_{\ln \mathrm{YF}}} \ln \left(\frac{y}{\breve{m}_{\mathrm{YF}}}\right)\right]$,

where $y$ is PGA value, $\Phi$ is the cumulative standard normal distribution of the logarithm of the sample of random values
Table 1. The fundamental scale of absolute numbers in AHP (Saaty, 2008).

\begin{tabular}{ll}
\hline $\begin{array}{l}\text { Intensity of } \\
\text { Importance }\end{array}$ & Definition \\
\hline 1 & Equal importance \\
2 & Slight importance \\
3 & Moderate importance \\
4 & Moderate plus importance \\
5 & Strong importance \\
6 & Strong plus importance \\
7 & Very strong or demonstrated \\
& importance \\
9 & Very, very strong importance \\
9 & Extreme importance \\
\hline
\end{tabular}

of $\mathrm{Y}_{F}$, the minimum intensity required to produce overturning failure, $\sigma$ is the standard deviation of the natural $\log$ arithm, and $\breve{m}$ is the median value. Fig. 3 shows the overturning probability curves for hazardous appliances and less hazardous appliances (Reinoso et al., 2010).

The existence of an appliance depends on the type of occupancy of dwellings in a building. To assume all the same 


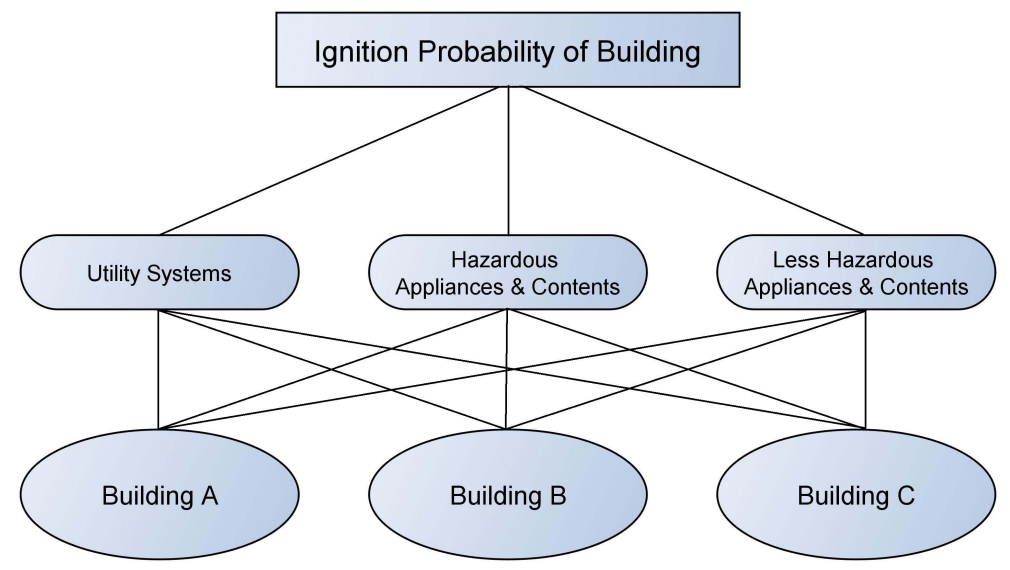

Fig. 4. Structure of AHP for post-earthquake ignition.

Table 2. Weights for the main components of post-earthquake ignition.

\begin{tabular}{lccc}
\hline Name & $\begin{array}{c}\text { Overall } \\
\text { Weights }\end{array}$ & $\begin{array}{c}\text { Weights (Earthquake } \\
\text { Engineers) }\end{array}$ & $\begin{array}{c}\text { Weights (Geomatics } \\
\text { Engineers) }\end{array}$ \\
\hline Utility System & 0.51588 & 0.39492 & 0.66098 \\
Hazardous Appliances & 0.38378 & 0.51128 & 0.23833 \\
Less Hazardous Appliances & 0.10034 & 0.09380 & 0.10069 \\
Consistency Ratios & 0.00094 & 0.00661 & 0.03263 \\
\hline
\end{tabular}

appliances and contents exist in all types of buildings is not a realistic approach. In order to make our model more reliable and realistic, a weighting factor is used to define the possibility of the existence of each appliance or object in a given type of occupancy.

Residential Energy Consumption Survey (RECS) and Commercial Buildings Energy Consumption Survey (CBECS) data from United States Energy Information Administration (USEIA) was used to produce probabilities for the existence of appliances. Then the existence probabilities of appliances and other contents, according to occupancy type, were calculated. HAZTURK (MAEViz) software is able to use this file in CSV (comma separated value) format.

Each component and subcomponent has a different level of significance in its contribution to post-earthquake ignition. The analytical hierarchy process (AHP) was used to weight the main and subcomponents. Figure 4 shows the structure of AHP for post-earthquake ignition. In Fig. 4, ignition probability of building is the aim, utility systems, hazardous and less hazardous appliances and contents and their subcomponents are the criteria and building A, B and C are the alternatives.

AHP is a method of prioritizing different components in decision making. The method is based on a pairwise comparison of components. The importance of components is determined by creating a pairwise comparison matrix. Pairwise comparisons should be performed by experts in the subject. The comparisons are made using a scale of absolute judge- ments that represents how much more one element dominates another, with respect to a given attribute (Table 1).

A questionnaire was prepared to rank in order of significance the different components of post-earthquake ignitions. The questionnaire was evaluated by scientists who were experienced in earthquake engineering and post-earthquake fires. Amongst them, 57\% were researchers in earthquake engineering departments and $43 \%$ of them worked in geomatics engineering departments, having experience in disaster management. The results were evaluated to calculate the significance of all the main components and subcomponents. According to the questionnaires, the overall weights of the main components and their consistency ratios are given in Table 2. The weights of the main components and their consistency ratios with respect to two different disciplines are also given in Table 2 and this also denotes the dissidence between the different perceptions of the post-earthquake ignition concept.

According to Table 2, while geomatics engineers consider the utility system as the most important component in postearthquake ignition, earthquake engineers consider the most important to be hazardous appliances. However, both disciplines agreed on less hazardous appliances being the least important component. 
Table 3. Number and structure types of buildings.

\begin{tabular}{llr}
\hline Structure Type & Definition & $\begin{array}{r}\text { Number of } \\
\text { Buildings }\end{array}$ \\
\hline C3 & Concrete frame with & 30151 \\
& unreinforced masonry & \\
infill walls & 75 \\
PC1 & Precast concrete tilt-up walls & 369 \\
RM & Reinforced masonry & 5534 \\
URM & Unreinforced masonry & \\
W1 & Bearing walls & 22 \\
\hline
\end{tabular}

\section{Application}

Turkey appears at top of the list of the most seismically active countries in the world. Parsons et al. (2000) and Parsons (2004) declared that the probability of a magnitude 7 earthquake from the Main Marmara Fault is approximately $35-70 \%$ within the next $30 \mathrm{yr}$, with an estimation of a rupture beneath the Sea of Marmara to the south of Istanbul. The seismic activity around the city of Istanbul also encouraged the researchers to develop advanced scientific models to estimate the possible losses during and following such an earthquake (Karaman et al., 2008).

There are 36151 buildings in the Küçükçekmece database. Most of these are concrete frame buildings with unreinforced masonry infill walls. The number of buildings with respect to their structure types is given in Table 3 . The building inventory is also given in a visual form in Fig. 5.

Most of the buildings were constructed between 1975 and 1997. The number of storeys was between 1 and 7 (Table 4).

The $0.2 \mathrm{~s}$ Sa (spectral acceleration) and PGA earthquake hazard maps (EHM) of the Küçükçekmece District in Figs. 6 and 7, respectively, were obtained from Erden and Karaman's (2012) study on the Küçükçekmece region for a 7.5 moment magnitude earthquake scenario on the Main Marmara Fault. The $0.2 \mathrm{~s}$ Sa based earthquake hazard map was used to estimate structural damage for buildings and a PGA based earthquake hazard map was used to estimate postearthquake ignition probability of buildings. The attenuation function for the EHM of this study was from Boore and Atkinson (2007), which is a study from the Next Generation Attenuation Models of the Pacific Earthquake Engineering Research (PEER) Center.

A building damage analysis was carried out to estimate damage probabilities for insignificant, moderate, heavy and complete damage states. Fragilities and building fragility mapping were taken from Karaman et al. (2008), which were developed for the Istanbul building inventory, and were used to complete the earthquake damage analysis. The attributes of the aforementioned inventory were formatted to match the HAZTURK software's data requirements as shown in Table 5.

\section{Küçükçekmece Building Inventory}

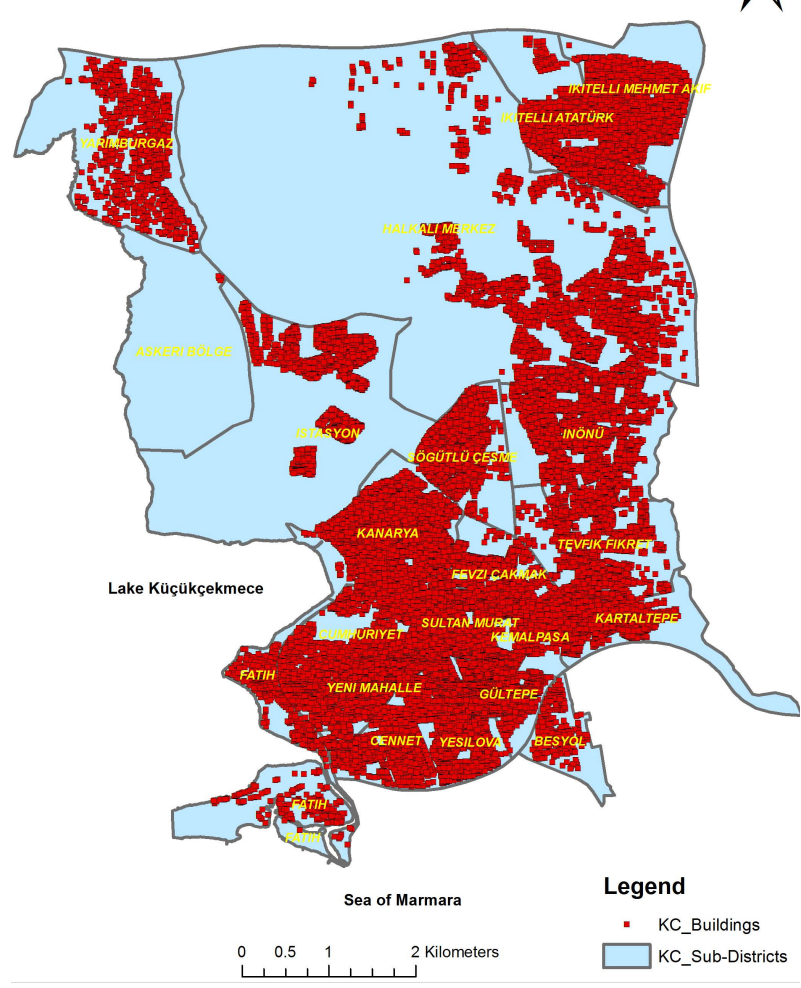

Fig. 5. Küçükçekmece building inventory.

The earthquake damage analysis for the buildings was run with respect to four damage states: insignificant, moderate, heavy and complete. The damage states are defined inside the parametric fragility curves of Istanbul. The parameterized fragility method (PFM) used in this study was developed by Jeong and Elnashai (2007) and offered as an "efficient tool for rapidly deriving probabilistic fragility relationships with quantifiable levels of uncertainty and especially useful for practical application of analytical fragility curves to the planning of seismic rehabilitation, and regional earthquake mitigation where fast estimation of probabilities of reaching damage states for a large number of structural configurations and different mitigation measures are required" (Jeong and Elnashai, 2007).

With respect to fragility curves and EHM of the study region, the earthquake damage analysis for the buildings of the Küçükçekmece District was run. The results of the analysis are given in Table 6 with reference to the structure types. Figure 8 envisages the building damage distribution of the region.

According to the results of the earthquake damage analysis for the buildings of the Küçükçekmece District, the most vulnerable buildings are URM and PC1 buildings. Respectively, they have 44 and $36 \%$ overall collapse probability. When the results are evaluated according to the number of storeys 


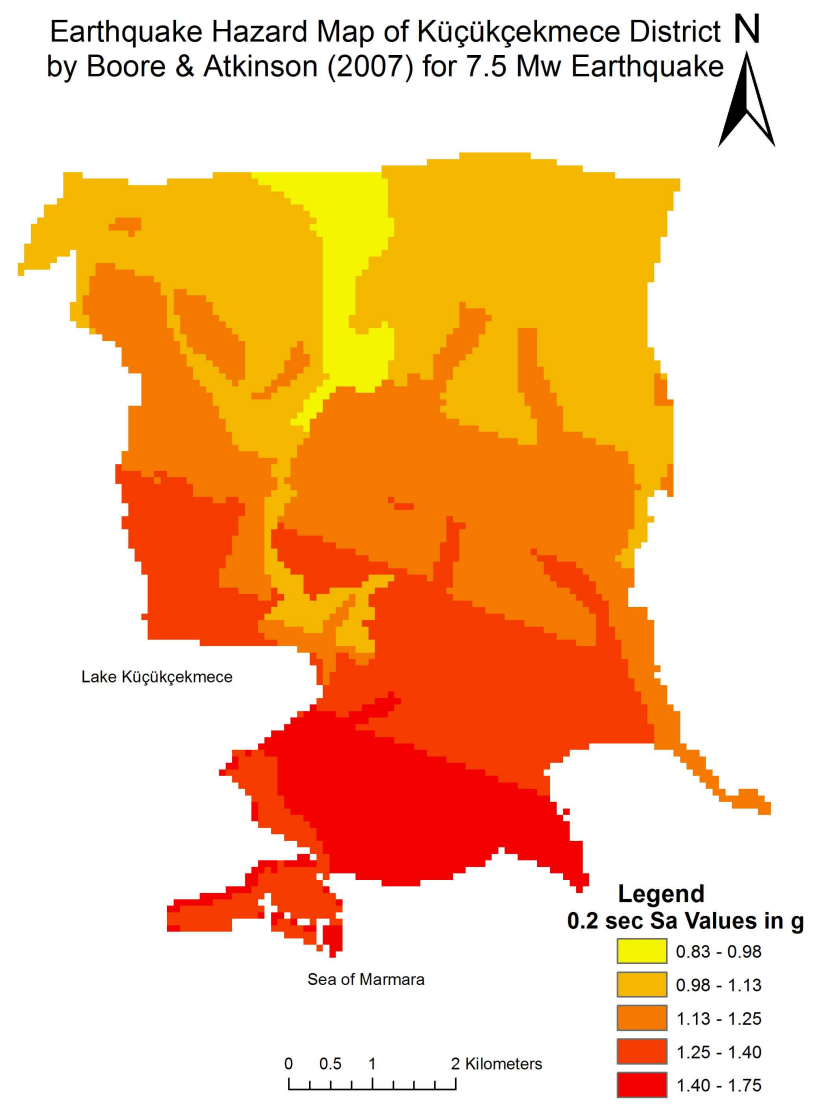

Fig. 6. A $0.2 \mathrm{~s}$ Sa earthquake hazard map of Küçükçekmece District.

of the buildings, 1-storey, 2-storey and 3-storey buildings are more vulnerable than the others. The 1-storey buildings have a $40 \%$ overall collapse probability. Another inference obtained from the results is that buildings constructed before 1975 are more vulnerable than buildings constructed after 1975 , with their overall collapse probability being between 40 and $50 \%$.

Post-earthquake ignition analysis was carried out, incorporating the building damage file, PGA distribution map and an appliance existence probability table. The required attributes for the building damage file are shown in Table 7. After the analysis, maximum ignition risk was determined as $46 \%$ for buildings in Küçükçekmece.

The results of the analysis are given in Table 8 with reference to the structure types in the form of mean ignition probabilities caused by utility systems $\left(P_{\mathrm{US}}\right)$, hazardous and less hazardous appliances $\left(P_{\mathrm{HA}}\right.$ and $\left.P_{\mathrm{LHA}}\right)$ and overall ignition probabilities $\left(P_{\mathrm{ig}}\right)$ respectively. Figure 9 visualizes the distribution of post-earthquake ignition probability for the region.

\section{Discussions and Conclusions}

According to the results of post-earthquake ignition analysis for the Küçükçekmece District, the most vulnerable build-

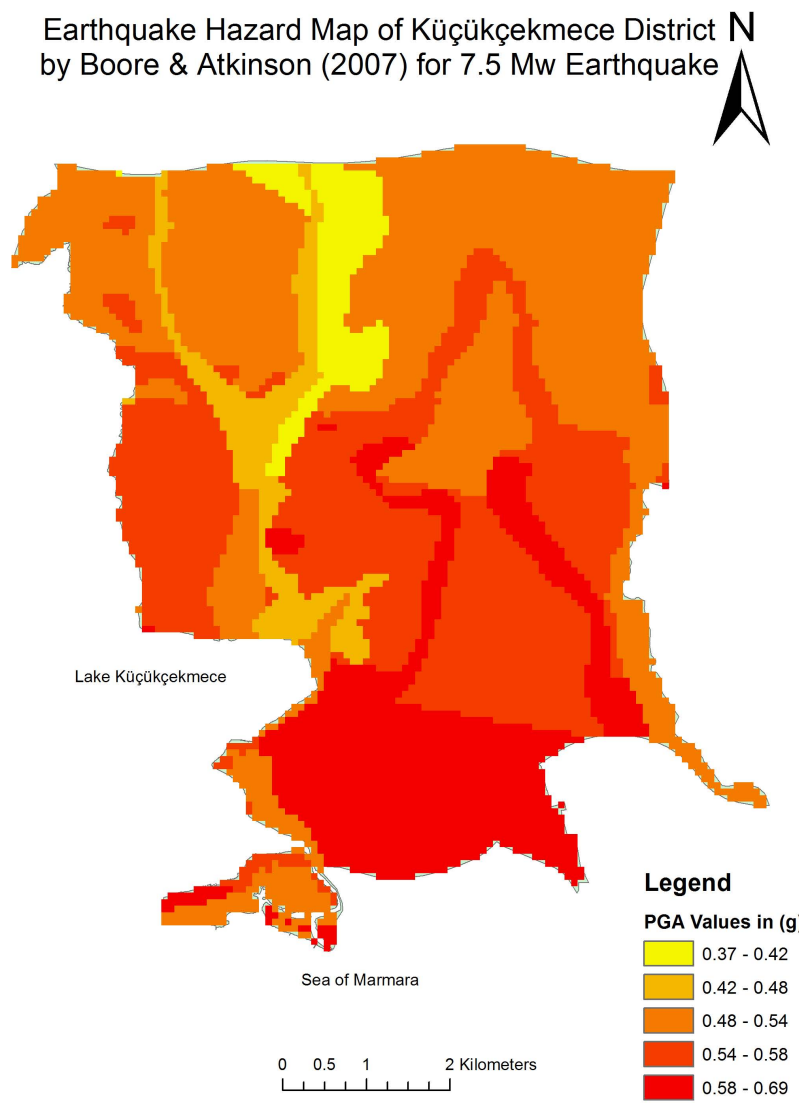

Fig. 7. PGA earthquake hazard map of Küçükçekmece District.

Table 4. Number of buildings according to number of stories.

\begin{tabular}{lcc}
\hline $\begin{array}{l}\text { Number of } \\
\text { Storeys }\end{array}$ & $\begin{array}{c}\text { Number of } \\
\text { Buildings }\end{array}$ & Percentage \\
\hline 1 & 5108 & 0.141 \\
2 & 5099 & 0.141 \\
3 & 6651 & 0.184 \\
4 & 7547 & 0.209 \\
5 & 5775 & 0.160 \\
6 & 3786 & 0.105 \\
7 & 2185 & 0.060 \\
\hline
\end{tabular}

ings are URM and PC1 buildings. They have a $39 \%$ overall collapse probability. When the results are evaluated according to the number of storeys of buildings, 1-storey, 2-storey and 3-storey buildings are more vulnerable than the others. The 1-storey buildings have a $37 \%$ overall collapse probability. Industrial buildings in the study region are more vulnerable to post-earthquake ignition than the other buildings, they also have a $37 \%$ overall ignition probability.

Another inference obtained from the results is that buildings constructed before 1975 are more vulnerable than buildings constructed after 1975 . The overall ignition probabilities of these buildings are between 37 and $44 \%$. This 
Table 5. Required attributes in building inventory data.

\begin{tabular}{lll}
\hline Attribute & Definition & Data Type \\
\hline Struct_Type & $\begin{array}{l}\text { General structure } \\
\text { type of the building } \\
\text { Broad HAZUS } \\
\text { occupancy category } \\
\text { Total number of stories }\end{array}$ & String (Text) \\
No_Stories & Integer \\
for the building & Integer \\
\hline
\end{tabular}

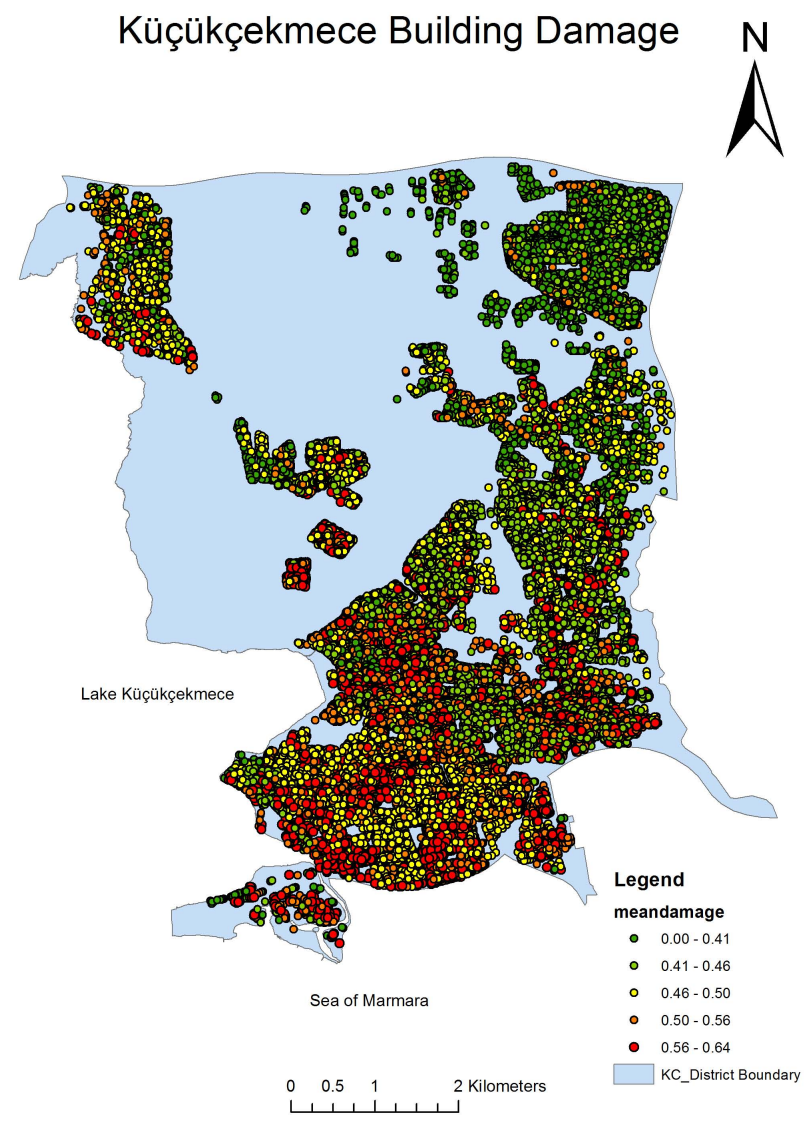

Fig. 8. Visualized results of earthquake damage analysis for the buildings.

demonstrates that collapsed buildings have a significant postearthquake ignition risk.

When the results are evaluated based on the subdistricts, the most vulnerable regions are Yenimahalle and Yeşilova. Both districts have a $38 \%$ overall ignition probability. Cennet and Cumhuriyet districts also have a postearthquake ignition risk, with a 37 and $36 \%$ ignition probability, respectively.

The number of wooden buildings is also important from the aspect of fire-spread. Wooden buildings that are exposed to intense shaking are seriously dangerous when the fire-
Küçükçekmece Buildings

Post-Earthquake Ignitions

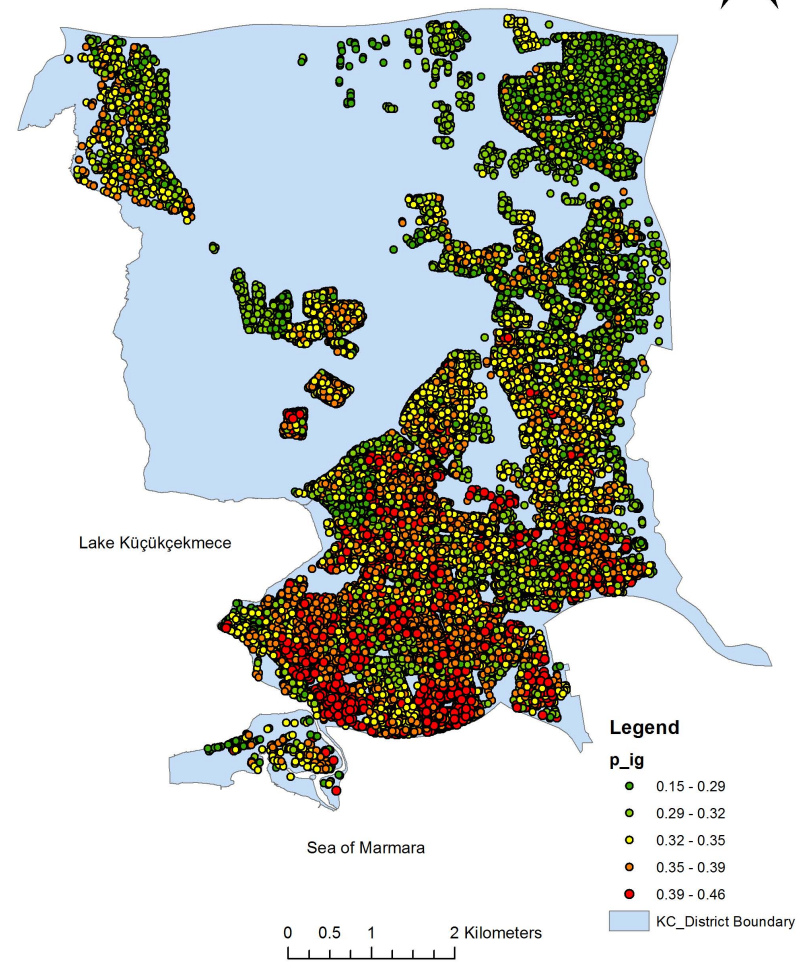

Fig. 9. Visualized results of post-earthquake ignition analysis.

spread potential of these types of buildings is considered. The spread of fire in wooden buildings is faster than other types of structure. This puts people in wooden buildings under a noteworthy risk. Wooden buildings have a $27 \%$ overall ignition probability and some of them have critical ignition probabilities. When the results of the analysis are examined, it is clear that post-earthquake ignition probability is inversely proportional to the number of storeys and construction year, depending on the building code. The results of the analyses given in Table 9 indicate that building damage and an exposed PGA value are of great significance in post-earthquake ignitions.

The distribution of mean building damage, PGA, and ignition probability are compared on a chart, based on their assessment results. According to the comparison, PGA and mean building damage values showed a close correlation with the ignition probability in the aspect of the trend line as seen in Fig. 10.

As future improvements, seasonal atmospheric conditions, use of appliances with respect to the seasons, and the spread of ignited fire to neighboring buildings are also planned to be added to the system in future studies. 
Table 6. Results of earthquake damage analysis for the buildings, with different damage states with respect to structure types.

\begin{tabular}{lccccc}
\hline $\begin{array}{l}\text { Structure } \\
\text { Type }\end{array}$ & $\begin{array}{c}\text { Insignificant } \\
(\%)\end{array}$ & $\begin{array}{c}\text { Moderate } \\
(\%)\end{array}$ & $\begin{array}{c}\text { Heavy } \\
(\%)\end{array}$ & $\begin{array}{c}\text { Complete } \\
(\%)\end{array}$ & $\begin{array}{c}\text { Mean Damage } \\
(\%)\end{array}$ \\
\hline C3 & 0.11 & 0.30 & 0.33 & 0.26 & 0.46 \\
PC1 & 0.08 & 0.22 & 0.35 & 0.36 & 0.55 \\
RM1 & 0.12 & 0.23 & 0.37 & 0.28 & 0.49 \\
URM & 0.09 & 0.20 & 0.27 & 0.44 & 0.58 \\
W1 & 0.18 & 0.43 & 0.23 & 0.11 & 0.29 \\
\hline
\end{tabular}

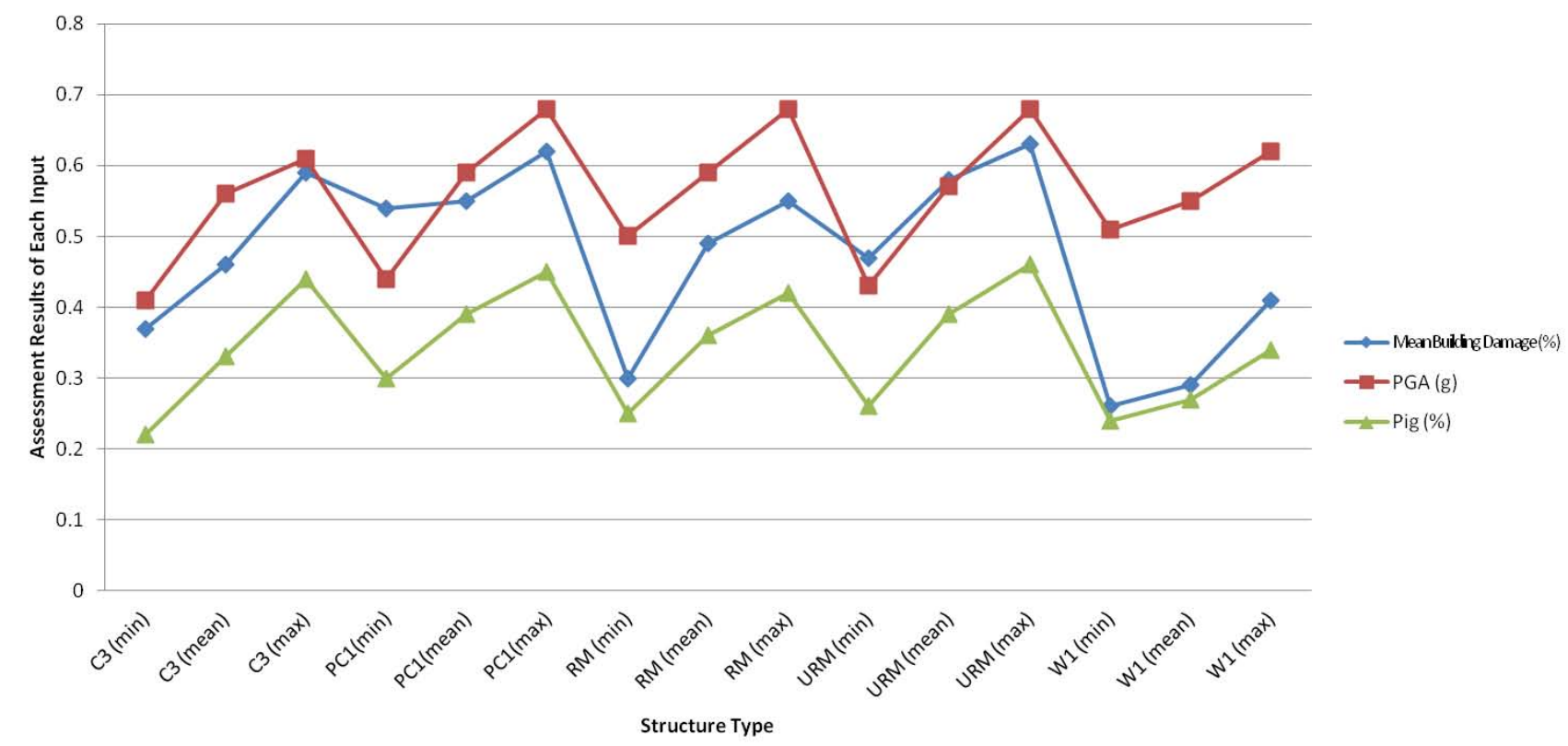

Fig. 10. Distribution of mean building damage, PGA, and ignition probability.

Table 7. Required attributes in building damage data.

\begin{tabular}{ll}
\hline Attribute & Data Type \\
\hline Occ_Type & String (Text) \\
Insignificant & Double \\
Moderate & Double \\
Heavy & Double \\
Complete & Double \\
\hline
\end{tabular}

Table 8. Results of post-earthquake ignition analysis for the buildings.

\begin{tabular}{lcccc}
\hline Structure Type & $P_{\mathrm{US}}(\%)$ & $P_{\mathrm{HA}}(\%)$ & $P_{\text {LHA }}(\%)$ & $P_{\text {ig }}(\%)$ \\
\hline C3 & 0.27 & 0.36 & 0.50 & 0.33 \\
PC1 & 0.35 & 0.40 & 0.53 & 0.39 \\
RM1 & 0.30 & 0.39 & 0.52 & 0.36 \\
URM & 0.36 & 0.39 & 0.51 & 0.39 \\
W1 & 0.18 & 0.33 & 0.50 & 0.27 \\
\hline
\end{tabular}

Table 9. Distribution of ignition probability with respect to building damage and PGA values.

\begin{tabular}{lccc}
\hline $\begin{array}{l}\text { Structure } \\
\text { Type }\end{array}$ & $\begin{array}{c}\text { Mean Building } \\
\text { Damage }(\%)\end{array}$ & PGA $(\mathrm{g})$ & $P_{\text {ig }}(\%)$ \\
\hline C3 (min) & 0.37 & 0.41 & 0.22 \\
C3 (mean) & 0.46 & 0.56 & 0.33 \\
C3 (max) & 0.59 & 0.61 & 0.44 \\
PC1 (min) & 0.54 & 0.44 & 0.30 \\
PC1(mean) & 0.55 & 0.59 & 0.39 \\
PC1(max) & 0.62 & 0.68 & 0.45 \\
RM (min) & 0.30 & 0.50 & 0.25 \\
RM (mean) & 0.49 & 0.59 & 0.36 \\
RM (max) & 0.55 & 0.68 & 0.42 \\
URM (min) & 0.47 & 0.43 & 0.26 \\
URM (mean) & 0.58 & 0.57 & 0.39 \\
URM (max) & 0.63 & 0.68 & 0.46 \\
W1 (min) & 0.26 & 0.51 & 0.24 \\
W1 (mean) & 0.29 & 0.55 & 0.27 \\
W1 (max) & 0.41 & 0.62 & 0.34 \\
\hline
\end{tabular}


Acknowledgements. This study is a part of Yildiz's PhD dissertation and authors acknowledge their co-advisor Amr Elnashai from the University of Illinois at Urbana-Champaign for creating the subject, aim and concept of the study. Without his ideas, contributions and guidance this study could not have been started and completed.

Edited by: R. Lasaponara

Reviewed by: F. Kilic and three anonymous referees

\section{References}

Aoki, Y.: Stochastic theory on outbreaks of fire following earthquake: Theoretical analyses on stochastic spread of fire in urban area, Part 4, J. Archit. Plann. Environ. Eng., 412, 52-60, 1990.

Boore, D. M. and Atkinson, G. M.: Boore-atkinson nga ground motion relations for the geometric mean horizontal component of peak and spectral ground motion parameters, Pacific Earthquake Engineering Research Center PEER 2007/01, 242 pp., 2007.

Cousins, W. and Smith, W.: Estimated losses due to post-earthquake fire in three New Zealand cities, Proceedings of New Zealand Society of Earthquake Engineering Conference, Institute of Geological \& Nuclear Sciences, Lower Hutt, New Zealand, 2004.

Davidson, R. A.: Modeling Postearthquake Fire Ignitions Using Generalized Linear (Mixed) Models, J. Infrastruct. Syst., 15, 351-360, 2009.

Erden, T. and Karaman, H.: Analysis of earthquake parameters to generate hazard maps by integrating AHP and GIS for Küçükçekmece region, Nat. Hazards Earth Syst. Sci., 12, 475483, 2012,

http://www.nat-hazards-earth-syst-sci.net/12/475/2012/.

Hamada, M.: On Fire Spreading Velocity in Disasters, Sagami Shobo, Tokyo, 1951.

HAZUS.: Technical Manual, Federal Emergency Management Agency, Washington, DC, 1999.

Horiuchi, S., Kobayashi, M., and Nakai, S.: Study on the Emergency Escape in City Area, Transactions of the Architectural Institute of Japan, 223, 45-71, 1974.

Hosseini, K. A., Hosseini, M., Jafari, M. K., and Hosseinioon, S.: Recognition of vulnerable urban fabrics in earthquake zones: a case study of the Tehran metropolitan area, J. Seismol. Earthquake Engin., 10, 175-187, 2009.

Jeong, S-H. and Elnashai, A. S.: Probabilistic fragility analysis parameterized by fundamental response quantities, Engineering Structures, 29, 1238-1251, 2007.

Karaman, H., Sahin, M., Elnashai, A. S., and Pineda, O.: Loss assessment study for the zeytinburnu district of Istanbul using Maeviz-Istanbul (HAZTURK), J. Earthq. Eng., 12, 187-198, 2008.

Kawasumi, H.: Examination of Earthquake-Fire Damage in Tokyo Metropolis, Technical Report, Tokyo Fire Department, Tokyo, 1961.

Kobayashi, M.: Urban post-earthquake fires in Japan, Proceedings, the Eight World Conference on Earthquake Engineering, Prentice-Hall, Englewood Cliffs, New Jersey, 1984.

Lee, S., Davidson, R., Ohnishi, N., and Scawthorn, C.: Fire Following Earthquake-Reviewing the State-of-the-Art of Modeling, Earthquake Spectra, 24, 4, 933-967, 2008.
Li, J., Jiang, J., and Li, M.: Hazard analysis system of urban postearthquake fire based in GIS, Acta Seismologica Sinica, 14, 448455, 2001.

Martin, S. B.: Fire setting by nuclear explosion: A revisit and use in nonnuclear applications, J. Fire Protect. Eng., 14, 283-297, 2004.

Mizuno, H.: On Outbreak of Fires in Earthquakes, PhD Dissertation, Kyoto Univ., Kyoto, 1978.

Mizuno, H. and Horiuchi, S.: Study on the prediction about the numbers of the outbreak of fires caused by the earthquakes, Trans. Architect. Instit. Japan, 250, 81-90, 1976.

Oppenheim, I. J.: Modeling earthquake-induced fire loss, Proceedings, Eighth World Conference on Earthquake Engineering, vol VII, 777-784, San Francisco, 1984.

Parsons, T.: Recalculated probability of $m=7$ earthquakes beneath the Sea of Marmara, Turkey, North, 109, 1-21, 2004.

Parsons, T., Toda, S., Stein, R. S., Barka, A., and Dieterich, J. H.: Heightened odds of large earthquakes near Istanbul: An interaction-based probability calculation, Science, 288, 661-665, 2000.

Peyghaleh, E.: Fire following earthquake risk analysis, a pilot study for the city of Tehran, MSc Dissertation, K.N. Toosi University of Technology, Tehran, Iran, 2006.

Reinoso, E., Jaimes, M. A., and Esteva, L.: Seismic vulnerability of an inventory of overturning objects, Journal of Earthquake Eng., 14, 1008-1021, 2010.

Ren, A. and Xie, X.: The simulation of post-earthquake fire-prone area based on GIS, J. Fire Sci., 22, 421-439, 2004.

Saaty, T. L.: Decision making with the analytic hierarchy process, Int. J. Services Sciences, 1, 83-98, 2008.

Scawthorn, C.: Simulation modeling of fire following earthquake, Proceedings, 3rd National Conference for Earthquake Engineering, 676-685, Charleston, SC, 1986.

Scawthorn, C.:Fire Following Earthquake-Estimates of the Con?agration Risk to Insured Property in Greater Los Angeles and San Francisco, Technical Report, All-Industry Research Advisory Council, Oak Park, IL, 1987.

Scawthorn, C., Yamada, Y., and Iemura, H.: A model for urban postearthquake fire hazard, Disasters, 5, 125-132, 1981.

Scawthorn, C.: Enhancements in HAZUS-MH, Fire Following Earthquake Task 3: Updated Ignition Equation. Technical Report, PBS\&J and the National Institute of Building Sciences, 2009.

Scawthorn, C., Eidinger, J. M., and Schiff, A. J.: Fire Following Earthquake, Technical Council on Lifeline Earthquake Engineering Monograph No. 26, American Society of Civil Engineers, Reston, 2005.

Scawthorn, C., O'Rourke, T.D., and Blackburn, F.T.: The 1906 San Francisco Earthquake and Fire-Enduring Lessons for Fire Protection and Water Supply, Earthquake Spectra, 22, S135-S158, 2006

Seligson, H., Ballantyne, D., Huyck, C., Eguchi, R., Buckham, S., and Burtugno, E.: URAMP (Utilities Regional Assessment of Regional Priorities)-A benefit-cost analysis tool for water, wastewater and drainage utilities: Methodology development, Proceedings, Technical Council on Lifeline Engineering Research, Long Beach, CA, 494-503, 2003. 
Steinbrugge, K.: Earthquake Hazard in the San Francisco Bay Area: A Continuing Problem in Public Policy, 80, Institute of Governmental Studies, University of California, Berkeley, 1968.

Steinbrugge, K.: San Fernando Earthquake, Pacific Fire Rating Bureau, 1971.

US Army: The Fukui Earthquake, Hokuriku Region, Japan, 28 June 1948, Office of the Engineer, General Headquarters, Far East Command, US Army, 1949.
Watabe, M., Dan, K., Sato, T., and Okumura, T.: Microzonation and disaster mitigation, in: Proceedings of Earthquake Engineering Tenth World Conference, Balkema, Rotterdam, Netherlands, 1924 July 1992, 6535-6549, 1994.

Zhao, S., Xiong, L., and Ren, A.: A spatial-temporal stochastic simulation of fire outbreaks following earthquake based on GIS, J. Fire Sci., 24, 313-339, 2006.

Zolfaghari, M. R., Peyghaleh, E., and Nasirzadeh, G.: Fire following earthquake, intrastructure ignition modeling, J. Fire Sciences, 27, 45-79, 2009. 